P-ISSN 2580 - 7781

E-ISSN 2615 - 3238

\title{
HUBUNGAN TERAPI RELAKSASI OTOT PROGRESIF DENGAN \\ PERUBAHAN TINGKAT INSOMNIA PADA LANSIA DI LKS-LU PANGESTI LAWANG DAN PANTI WERDHA TRESNO MUKTI TUREN
}

\section{THE RELATION OF PROGRESSIVE MUSCLE RELAXATION THERAPY WITH CHANGES IN THE LEVEL OF INSOMNIA IN THE LKS-LU PANGESTI LAWANG AND PANTI WERDHA TRESNO MUKTI TUREN}

\author{
Ellia Ariesti ${ }^{1)}$, Monika Luhung ${ }^{2)}$, Yafet Pradikatama P. ${ }^{3)}$, Nanta Sigit ${ }^{4)}$ \\ 1,2,3,4 Jurusan Keperawatan, STIKes Panti Waluya Malang \\ Email : ${ }^{1}$ ellianathanael@gmail.com
}

\begin{abstract}
ABSTRAK
Populasi lansia meningkat sangat cepat. Tahun 2020, jumlah lansia diprediksi sudah menyamai jumlah balita. Sebagai populasi berisiko ini memiliki tiga karakteristik risiko kesehatan yaitu, risiko biologi termasuk risiko terkait usia, risiko sosial dan lingkungan serta risiko perilaku atau gaya hidup. Pola tidur harian yang berubah merupakan perubahan paling terlihat pada usia lanjut. Ada beberapa dampak serius gangguan tidur pada lansia misalnya mengantuk berlebihan di siang hari, gangguan atensi dan memori, mood depresi, sering terjatuh. Tujuan penelitian ini adalah mengetahui hubungan terapi relaksasi otot progresif dengan perubahan tingkat insomnia pada lansia Di LKS-LU Pangesti Lawang dan Panti Werdha Panti Werdha Tresno Mukti Turen. Jenis penelitian yang digunakan dalam penelitian ini adalah penelitian quasy eksperimen dengan pendekatan pre test dan post tes pada kelompok perlakuan. Populasi dalam penelitian ini adalah semua lansia yang tinggal di LKS-LU Pangesti Lawang dan Panti Werdha Panti Werdha Tresno Mukti Turen dengn jumlah sampel sebanyak 29 responden. Hasil analisis bivariat menggunakan uji chi-square. Berdasarkan hasil dari analisa regresi logistic biner diketahui bahwa terdapat hubungan antara tingkat insomnia pre dengan relaksasi otot progresif. Nilai uji Wald yang dihasilkan sebesar 0.419 dengan sig. $0,038(<0,05)$ yang menujukkan terdapat hubungan yang signifikan antara tingkat insomnia pre terhadap relaksasi otot progresif dan terdapat hubungan antara tingkat insomnia post dengan relaksasi otot progresif. Nilai uji Wald yang dihasilkan sebesar 0.401 dengan sig. $0,028(<$ $0,05)$ yang menujukkan terdapat hubungan yang signifikan antara tingkat insomnia post terhadap relaksasi otot progresif.
\end{abstract}

Kata Kunci: Terapi, Relaksasi, Otot Progresif, Insomnia, Lansia

\begin{abstract}
The elderly population is increasing very rapidly. In 2020, the number of elderly is predicted to match the number of toddlers. As a population at risk, it has three health risk characteristics, namely, biological risks including age-related risks, social and environmental risks and behavioral or lifestyle risks. Changing daily sleep patterns are the most visible changes in old age. There are several serious effects of sleep disorders in the elderly, such as excessive daytime sleepiness, attention and memory disorders, depressed mood, frequent falls. The purpose of this study was to determine the relationship between progressive muscle relaxation therapy and changes in the level of insomnia in the elderly at LKS-LU Pangesti Lawang and Panti Werdha Panti Werdha Tresno Mukti Turen. This type of research used in this research is a quasy experimental
\end{abstract}


P-ISSN $2580-7781$

E-ISSN 2615 - 3238

research with pre-test and post-test approaches in the treatment group. The population in this study were all elderly living in LKS-LU Pangesti Lawang and Panti Werdha Tresno Mukti Turen Nursing Home with a total sample of 29 respondents. The results of the bivariate analysis used the chi-square test. Based on the results of the binary logistic regression analysis, it is known that there is a relationship between the level of pre insomnia and progressive muscle relaxation. The resulting Wald test value is 0.419 with sig. $0.038(<0.05)$, which shows that there is a significant relationship between the level of pre insomnia and progressive muscle relaxation and there is a relationship between the level of post insomnia and progressive muscle relaxation. The resulting Wald test value is 0.401 with sig. 0.028 (<0.05), which indicates that there is a significant relationship between the level of post insomnia and progressive muscle relaxation.

Keywords: Therapy, Relaxation, Progressive Muscle, Insomnia, Elderly

\section{PENDAHULUAN}

Populasi lansia meningkat sangat cepat. Tahun 2020, jumlah lansia diprediksi sudah menyamai jumlah balita. Sebelas persen dari 6,9 milyar penduduk dunia adalah lansia (WHO, 2013). Populasi penduduk Indonesia merupakan populasi terbanyak keempat sesudah China, India dan Amerika Serikat. Menurut data World Health Statistic 2013, penduduk China berjumlah 1,35 milyar, India 1,24 milyar, Amerika Serikat 313 juta dan Indonesia berada di urutan keempat dengan 242 juta penduduk (WHO, 2013). Menurut proyeksi Badan Pusat Statistik (2013) pada 2018 proporsi penduduk usia 60 tahun ke atas sebesar 24.754 .500 jiwa $(9,34 \%)$ dari total populasi.

Lansia merupakan salah satu kelompok atau populasi berisiko (population at risk) yang semakin meningkat jumlahnya. Allender, Rector, dan Warner (2014) mengatakan bahwa populasi berisiko (population at risk) adalah kumpulan orang-orang yang masalah kesehatannya memiliki kemungkinan akan berkembang lebih buruk karena adanya faktor-faktor risiko yang memengaruhi. Stanhope dan Lancaster (2016) mengatakan lansia sebagai populasi berisiko ini memiliki tiga karakteristik risiko kesehatan yaitu, risiko biologi termasuk risiko terkait usia, risiko sosial dan lingkungan serta risiko perilaku atau gaya hidup.

Pola tidur harian yang berubah merupakan perubahan paling terlihat pada usia lanjut. Perubahan ini sudah lazim sehingga sering disalah mengertikan sebagai proses tidur normal seiring bertambahnya usia. Namun informasi baru menunjukkan bahwa banyak gangguan semacam ini tidak normal. Berdasarkan penelitian medis umumnya orang mempunyai kesulitan tidur cenderung lebih 
P-ISSN 2580 - 7781

E-ISSN 2615 - 3238

khawatir dan tertekan, kurang bahagia, lebih mengantuk atau secara mental lelah, mempunyai lebih banyak kekhawatiran mengenai pekerjaan dan masalah pribadi, dan kurang mempunyai rasa percaya diri dan harga diri dibanding kelompok yang dapat tidur teratur (Subandi, Lestari dan Suprianto, 2013).

Insomnia merupakan salah satu gangguan utama dalam memulai dan mempertahankan tidur di kalangan lansia. Insomnia didefinisikan sebagai suatu keluhan tentang kurangnya kualitas tidur yang disebabkan oleh satu dari sulit memasuki tidur, sering terbangun malam kemudian kesulitan untuk kembali tidur, bangun terlalu pagi, dan tidur yang tidak nyenyak (Joewana dalam Triyadini, 2010). Ada beberapa dampak serius gangguan tidur pada lansia misalnya mengantuk berlebihan di siang hari, gangguan atensi dan memori, mood depresi, sering terjatuh, penggunaan hipnotik yang tidak semestinya, dan penurunan kualitas hidup (N Amir, 2007).

Peningkatan pemenuhan kebutuhan tidur dapat dilakukan dengan mengajarkan cara-cara yang dapat menstimulus dan memotivasi tidur. Salah satu cara yang bisa dilakukan adalah relaksasi. Relaksasi merupakan suatu bentuk teknik yang melibatkan pergerakan anggota badan dan bisa dilakukan dimana saja (Potter \& Perry, 2005). Metode relaksasi terdiri dari beberapa macam diantaranya adalah relaksasi otot progresif (progressive muscle relaxation), pernapasan diafragma, imagery training, biofeedback, dan hipnosis (Miltenberger, 2004). Relaksasi ini diperkenalkan oleh Edmund Jacobson pada tahun 1938 (Conrad dan Roth dalam Ismayadi, 2009). Teknik relaksasi otot progresif ini mungkin lebih unggul dari pada teknik lain, memperlihatkan pentingnya menahan respons stres dengan mencoba meredakan ketegangan otot secara sadar (Devi Yulianti, 2003) Selain untuk memfasilitasi tidur, relaksasi otot progresif juga bermanfaat untuk ansietas, mengurangi kelelahan, kram otot serta nyeri leher dan punggung (Berstein, Borkovec, dan Steven, dalam Fitrisyia, 2005).

Prevalensi kejadian Lansia yang mengalami insomnia di LKS-LU Pangesti Lawang, Malang dan Panti Werdha Tresno Mukti Turen, Malang adalah sebanyak 20 dari 62 lansia yang tinggal di LKS-LU Pangesti Lawang Malang 
P-ISSN $2580-7781$

E-ISSN 2615 - 3238

dan sebanyak 15 lansia yang mengalami insomnia di Panti Werdha Tresno Mukti Turen, Malang dari total 42 lansia. Sehingga dengan adanya penelitian ini diharapkan dapat memberikan kontribusi pada tercapainya kebutuhan istirahat tidur sehingga juga akan menurunkan tingkat insomnia pada lansia.

Pada penelitian ini dilakukan untuk mengetahui hubungan terapi relaksasi otot progresif dengan perubahan tingkat insomnia pada lansia di LKS-LU Pangesti Lawang dan Panti Werdha Panti Werdha Tresno Mukti Turen.

\section{METODE PENELITIAN}

Desain penelitian yang digunakan dalam penelitian ini adalah quasy eksperimen dengan pendekatan pre test dan post tes pada kelompok perlakuan. Penelitian ini mengukur hubungan terapi relaksasi otot progresif dengan perubahan tingkat insomnia pada lansia di LKS-LU Pangesti Lawang dan Panti Werdha Tresno Mukti Turen. Penelitian ini memberikan perlakuan pada kelompok perlakuan melalui pemberian terapi relaksasi otot progresif terhadap perubahan tingkat insomnia kepada lansia. Pengaruh perlakuan dlihat pada perbedaan terhadap perubahan tingkat insomnia pada lansia, sebelum dan sesudah diberikan perlakuan.

Populasi dalam penelitian ini adalah semua lansia yang tinggal di LKS-LU Pangesti Lawang dan Panti Werdha Panti Werdha Tresno Mukti Turen dengn jumlah sampel sebanyak 29 responden. Dalam penelitian ini, teknik sampling yang digunakan secara non probability sampling dengan teknik purposive sampling atau judgement sampling, yaitu cara pengambilan sampel dilakukan dengan memilih sampel yang memenuhi kriteria penelitian sampel kurung waktu tertentu sehingga jumlah sampel terpenuhi (Setiadi, 2013).

Instrumen dalam penelitian ini dengan metode angket yaitu dengan menggunkan kuesioner. Kuesioner yang digunakan dalam penelitian ini adalah KSPBJ-IRS (Kelompok Studi Psikiatri Biologi Jakarta - Insomnia Rating scale) (Iskandar \& Setyonegoro, 1985) (Ramaita JURNAL FK UNAND 2010) yang telah dimodifikasi sesuai dengan kondisi lansia dan lembar Terapi Relaksasi Otot Progresif. 
P-ISSN 2580 - 7781

E-ISSN 2615 - 3238

\section{HASIL PENELITIAN DAN PEMBAHASAN}

Berdasarkan hasil penilitian akan dijelaskan mengenai hubungan struktural yang ada dalam kontek kerangka penelitian yang diilustrasikan dalam Gambar 1 berikut ini.

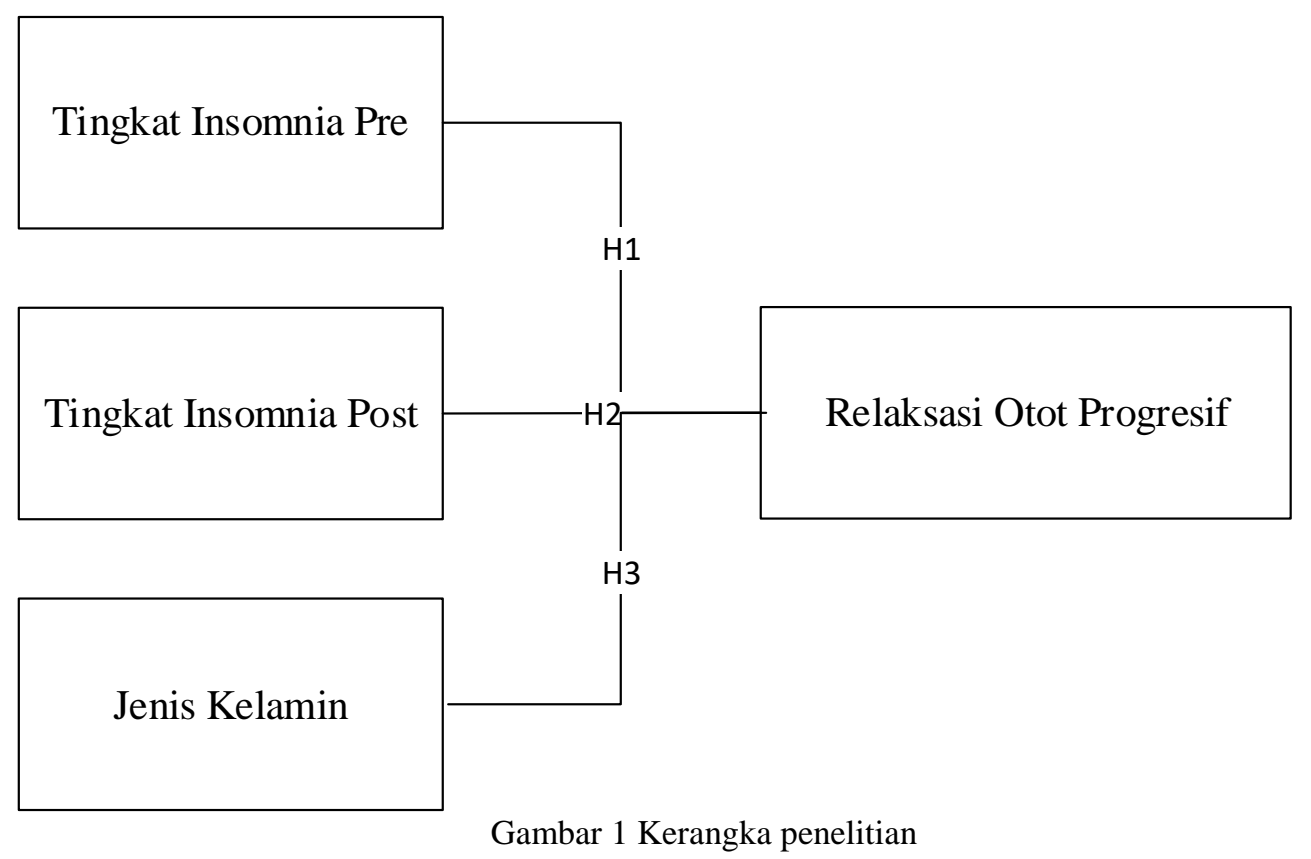

Hubungan struktural yang dianalisa adalah berdasarkan research question yang berada pada gambar diatas. Analisa dimulai dengan melihat adanya hubungan variabel tingkat insomnia pre (X1), variabel tingkat insomnia post (X2), variabel jenis kelamin (X3) berpengaruh terhadap relaksasi otot progresif (Y)

\begin{tabular}{|rl|r|r|r|}
\hline & & Chi-square & \multicolumn{1}{|c|}{ Df } & \multicolumn{1}{c|}{ Sig. } \\
\hline & Step & 10.095 & 4 & .039 \\
Step 1 & Block & 10.095 & 4 & .039 \\
& Model & 10.095 & 4 & .039 \\
\hline
\end{tabular}

Dari uji hipotesis untuk uji overall maka didapatkan bahwa ada salah satu diantara parameter yang tidak sama dengan 0. Hal ini menunjukkan bahwa model yang didapatkan signifikan. Selanjutnya untuk mengetahui variabel mana yang tidak sama dengan 0 perlu dilakukan uji parsial.

Tabel 1 Model Summary

\begin{tabular}{|l|c|r|c|}
\hline Step & $\begin{array}{c}-2 \text { Log } \\
\text { likelihood }\end{array}$ & $\begin{array}{c}\text { Cox \& Snell } \\
\text { R Square }\end{array}$ & $\begin{array}{c}\text { Nagelkerke } \\
\text { R Square }\end{array}$ \\
\hline 1 & $28.401^{\mathrm{a}}$ & .294 & .571 \\
\hline
\end{tabular}


P-ISSN 2580 - 7781

E-ISSN 2615 - 3238

a. Estimation terminated at iteration number 20 because maximum iterations has been reached.

Final solution cannot be found.

Nilai Negelkerke R Square menunjukan nilai koefisien determinasi. Di dapat nilainya 0,571 yang artinya $57,1 \%$ pengaruh seluruh variabel independent terhadap variabel Dependen.

Tabel 2 Hosmer and Lemeshow Test

\begin{tabular}{|c|c|c|c|}
\hline Step & Chi-square & $\mathrm{df}$ & Sig. \\
\hline 1 & 2.370 & 5 & .796 \\
\hline
\end{tabular}

Merupakan uji kelayakan model, dimana hipotesanya Ho: Model Layak dan H1: Model tdk Layak. Hasil uji menunjukan nilai Sig 0,796 yang artinya model Layak

Tabel 3 Variables in the Equation

\begin{tabular}{|l|r|r|r|r|r|r|}
\hline & \multicolumn{1}{|c|}{ B } & \multicolumn{1}{c|}{ S.E. } & Wald & \multicolumn{1}{c|}{ df } & \multicolumn{1}{c|}{ Sig. } & Exp(B) \\
\hline Jenis(1) & 1.067 & .974 & 1.201 & 1 & .043 & 2.907 \\
Insomnia_Pre(1) & -.623 & .963 & .419 & 1 & .038 & .536 \\
Insomnia_Post & & & .401 & 2 & .028 & \\
Step 1 $^{\text {a }}$ Insomnia_Post(1 & 20.514 & 14911.306 & .000 & 1 & .019 & 811107431.1 \\
& & & & & & 03 \\
Insomnia_Post(2 & -.926 & 1.462 & .401 & 1 & .017 & .396 \\
) & .693 & 1.225 & .320 & 1 & .011 & 2.000 \\
\hline
\end{tabular}

a. Variable(s) entered on step 1: Jenis, Insomnia_Pre, Insomnia_Post.

Tabel 3 Variable in the equation di atas, perhatikan nilai Wald dan nilai signifikansinya. Variabel independen signifikan semua karena variabel jenis kelamin (X3) sebesar 1,201 dengan sig. 0,043 $(<0,05)$, variabel Tingkat Insomnia Pre (X1) sebesar 0.419 dengan sig. 0,038 $(<0,05)$, variabel Tingkat Insomnia Post (X2) sebesar 0.401 dengan sig. 0,028 $(<0,05)$. Hal ini menunjukkan faktor jenis kelamin, Tingkat Insomnia pre, Tingkat Insomnia post berpengaruh terhadap Relaksasi Otot Progresif. 


\section{P-ISSN 2580 - 7781}

E-ISSN 2615 - 3238

1. Hubungan Tingkat Insomnia Pre dengan Relaksasi Otot Progresif

Berdasarkan hasil hipotesis 1 dari analisa regresi logistic biner diketahui bahwa terdapat hubungan antara tingkat insomnia pre dengan relaksasi otot progresif. Nilai uji Wald yang dihasilkan sebesar 0.419 dengan sig. 0,038 $(<0,05)$ yang menujukkan terdapat hubungan yang signifikan antara tingkat insomnia pre terhadap relaksasi otot progresif. Hal ini mendukung studi literatur terdahulu yang menunjukkan hubungan antara tingkat insomnia pre dengan relaksasi otot progresif. Hal ini dikarenakan, Penelitian yang dilakukan Erliana, Haroen, Susanti (2008), yaitu penelitian untuk mencari perbedaan tingkat insomnia lansia sebelum dan sesudah latihan relaksasi otot progresif, dari penelitian tersebut didapatkan perbedaan yang signifikan terhadap tingkat insomnia lansia sebelum dan sesudah latihan relaksasi progresif. Relaksasi progresif adalah memusatkan suatu perhatian pada suatu aktivitas otot dengan mengidentifikasi otot yang tegang kemudian menurunkan ketegangan dengan melakukan teknik relaksai, untuk mendapat perasaan relaksasi (Townsend, 2010). Relaksasi progresif merupakan kombinasi latihan pernafasan yang terkontrol dengan angkaian kontraksi serta relaksasi otot (P. A. Potter \& Perry, 2005). Relaksasi progresif adalah teknik relaksasi otot dalam yang memerlukan imajinasi dan sugesti (Davis, 2008). Disisi lain, Menurut Setyoadi (2011) bahwa tujuan dari relaksasi progresif adalah

1. Menurunkan ketegangan otot, kecemasan, nyeri leher dan punggung, tekanan darah tinggi, frekuensi jantung, dan laju metabolic

2. Mengurangi distritmia jantung, kebutuhan oksigen

3. Meningkatkan gelombang alfa otak yang terjadi ketika klien sadar dan tidak memfokus perhatian seperti relaks

4. Meningkatkan rasa kebugaran, konsentrasi.

5. Memperbaiki kemampuan untuk mengatasi stres.

6. Mengatasi insomnia

7. Membangun emosi dari emosi negatif

Sedangkan, menurut (Davis, 2008) relaksasi progresif memberikan hasil yang memuaskan dalam program terapi terhadap ketegangan otot, menurunkan ansietas, memfalisitasi tidur, depresi, mengurangi kelelahan, kram otot, nyeri pada leher dan 
P-ISSN 2580 - 7781

E-ISSN 2615 - 3238

punggung, menurunkan tekanan darah tinggi, fobia ringan serta meningkatkan konsentrasi. Target yang tepat dan jelas dalam memberikan relaksasi progresif pada keadaan yang memiliki respon ketegangan otot yang cukup tinggi dan membuat tidak nyaman sehingga dapat mengganggu kegiatan sehari-hari. Menurut McGuidan \& Lehrer (2007), dalam melakukan relaksasi progresif hal yang paling penting dikenali adalah ketegangan otot, ketika otot berkontraksi (tegang) maka rangsangan akan disampaikan ke otak melalui jalur saraf afferent. Tenson merupakan kontraksi dari serat otot rangka yang menghasilkan sensasi tegangan. Relaksasi adalah pemanjangan dari serat otot tersebut yang dapat menghilangkan sensasi ketegangan. Setelah memahami dalam mengidentifikasi sensasi tegang, kemudian dilanjutkan dengan merasakan relaks, ini merupakan sebuah prosedur umum untuk mengidentifikasi lokalisasi, relaksasi dan merasakan perbedaan antara keadaan tegang (tension) dan relaksasi yang akan diterapkan pada semua kelompok otot utama.

\section{Hubungan Tingkat Insomnia Post dengan Relaksasi Otot Progresif}

Berdasarkan hasil hipotesis 2 dari analisa regresi logistic biner diketahui bahwa terdapat hubungan antara tingkat insomnia post dengan relaksasi otot progresif. Nilai uji Wald yang dihasilkan sebesar 0.401 dengan sig. $0,028(<0,05)$ yang menujukkan terdapat hubungan yang signifikan antara tingkat insomnia post terhadap relaksasi otot progresif. Hal ini mendukung studi literatur terdahulu yang menunjukkan hubungan antara tingkat insomnia post dengan relaksasi otot progresif. Hal ini dikarenakan, Penelitian yang dilakukan Erliana, Haroen, Susanti (2008), yaitu penelitian untuk mencari perbedaan tingkat insomnia lansia sebelum dan sesudah latihan relaksasi otot progresif, dari penelitian tersebut didapatkan perbedaan yang signifikan terhadap tingkat insomnia lansia sebelum dan sesudah latihan relaksasi progresif.

Relaksasi progresif adalah memusatkan suatu perhatian pada suatu aktivitas otot dengan mengidentifikasi otot yang tegang kemudian menurunkan ketegangan dengan melakukan teknik relaksai, untuk mendapat perasaan relaksasi (Townsend, 2010). Relaksasi progresif merupakan kombinasi latihan pernafasan yang terkontrol dengan rangkaian kontraksi serta relaksasi otot (P. A. Potter \& Perry, 
P-ISSN $2580-7781$

E-ISSN 2615 - 3238

2005). Relaksasi progresif adalah teknik relaksasi otot dalam yang memerlukan imajinasi dan sugesti (Davis, 2008). Disisi lain, Menurut Setyoadi (2011) bahwa tujuan dari relaksasi progresif adalah

1. Menurunkan ketegangan otot, kecemasan, nyeri leher dan punggung, tekanan darah tinggi, frekuensi jantung, dan laju metabolic

2. Mengurangi distritmia jantung, kebutuhan oksigen

3. Meningkatkan gelombang alfa otak yang terjadi ketika klien sadar dan tidak memfokus perhatian seperti relaks

4. Meningkatkan rasa kebugaran, konsentrasi.

5. Memperbaiki kemampuan untuk mengatasi stres.

6. Mengatasi insomnia

7. Membangun emosi dari emosi negatif

Sedangkan, menurut (Davis, 2008) relaksasi progresif memberikan hasil yang memuaskan dalam program terapi terhadap ketegangan otot, menurunkan ansietas, memfalisitasi tidur, depresi, mengurangi kelelahan, kram otot, nyeri pada leher dan punggung, menurunkan tekanan darah tinggi, fobia ringan serta meningkatkan konsentrasi. Target yang tepat dan jelas dalam memberikan relaksasi progresif pada keaadaan yang memiliki respon ketegangan otot yang cukup tinggi dan membuat tidak nyaman sehingga dapat mengganggu kegiatan sehari-hari. Menurut Mc Guidan \& Lehrer (2007), dalam melakukan relaksasi progresif hal yang paling penting dikenali adalah ketegangan otot, ketika otot berkontraksi (tegang) maka rangsangan akan disampaikan ke otak melalui jalur saraf afferent. Tenson merupakan kontraksi dari serat otot rangka yang menghasilkan sensasi tegangan. Relaksasi adalah pemanjangan dari serat otot tersebut yang dapat menghilangkan sensasi ketegangan. Setelah memahami dalam mengidentifikasi sensasi tegang, kemudian dilanjutkan dengan merasakan relaks, ini merupakan sebuah prosedur umum untuk mengidentifikasi lokalisasi, relaksasi dan merasakan perbedaan antara keadaan tegang (tension) dan relaksasi yang akan diterapkan pada semua kelompok otot utama. 
P-ISSN 2580 - 7781

E-ISSN 2615 - 3238

3. Hubungan Jenis Kelamin dengan Relaksasi Otot Progresif

Berdasarkan hasil hipotesis 3 dari analisa regresi logistic biner diketahui bahwa terdapat hubungan antara jenis kelamin dengan relaksasi otot progresif. Nilai uji Wald yang dihasilkan adalah 3.723 ( $\mathrm{p}<0.05$ ) yang menujukkan terdapat hubungan yang signifikan antara jenis kelamin terhadap relaksasi otot progresif (Y). Berdasarkan literature review belum ada suatu penelitian mengenai hubungan antara jenis kelamin dengan relaksasi otot progresif, sehingga peneliti ingin mengetahui hubungan tersebut.

\section{KESIMPULAN}

Berdasarkan hasil dari analisa regresi logistic biner diketahui bahwa terdapat hubungan antara tingkat insomnia pre dengan relaksasi otot progresif. Nilai uji Wald yang dihasilkan sebesar 0.419 dengan sig. 0,038 $(<0,05)$ yang menujukkan terdapat hubungan yang signifikan antara tingkat insomnia pre terhadap relaksasi otot progresif dan terdapat hubungan antara tingkat insomnia post dengan relaksasi otot progresif. Nilai uji Wald yang dihasilkan sebesar 0.401 dengan sig. 0,028 $(<0,05)$ yang menujukkan terdapat hubungan yang signifikan antara tingkat insomnia post terhadap relaksasi otot progresif.

\section{DAFTAR PUSTAKA}

Allender, J.A., Rector, C., \& Warner, K.D.2014. Community dan public health nursing promoting the public's health (8th Ed.). Philadelphia: Lippincott Williams \& Wilkins.

Amir, N.2007. Gangguan Tidur Pada Lanjut Usia Diagnosa Dan Penatalaksanaan. Tinjauan Pustaka. Jakarta: Bagian Psikiatri Fakultas Kedokteran Universitas Indonesia.

Conrad, A., \& Roth, W. T.2007. Muscle Relaxation Therapy For Anxiety Disorders. Journal Of Anxiety Disorders. Vol. 21 hal 150-152

Kurniawan, Tommy.2012. Faktor-Faktor Yang Mempengaruhi Gangguan Tidur (Insomnia) Pada Lansia Di Panti Tresna Werdha Kabupaten Magetan. Online [http://scholar.google.com/scholar].

Miltenberger. 2004. Relaksasi. Available online at http//www.eworldindonesia.com 
P-ISSN 2580 - 7781

E-ISSN 2615 - 3238

Mashudi. 2011. Pengaruh Progressive Muscle Relaxation Terhadap Kadar Glukosa Darah Pasien Diabetes Tipe 2 Di Rumah Sakit Umum Daerah Raden Mattaher Jambi. Online [http://www.lontar.ui.ac.id/mashudi]

Potter \& Perry. 2005. Buku ajar fundamental keperawatan edisi 4. Jakarta : EGC.

Stanhope, M and Lancaster, J. 2016. Community public health nursing. St. LouisMissouri: Mosby

Subandi, Lestari R \& Suprianto T.2013. Pengaruh Terapi Psikoreligius Terhadap Penurunan Tingkat Ansietas Pada Lansia di UPT Pelayanan Sosial Lanjut Usia Sejahtera Pandaan Pasuruan.

Triyadini, Asrin, Upoyo, A. S. 2010. Efektifitas Terapi Massage dengan Terapi Mandi Air Hangat Terhadap Penurunan Insomnia Lansia. Jurnal Keperawatan Soedirman, 5(3), 174-180.

WHO. 2013. Ageing and life course. The World Health Organization Quality of Life. Geneva: World Health Organization 